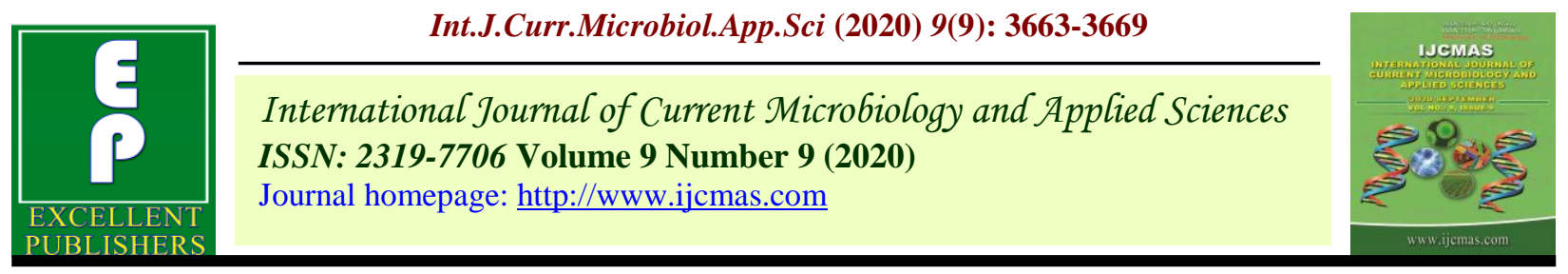

Original Research Article

https://doi.org/10.20546/ijcmas.2020.909.452

\title{
Production Potential of Oilseed - Pulses Cropping Systems under rainfed Ecology of Shivalik Foothills of Jammu
}

\author{
Rakesh Kumar*, B.C. Sharma, Abhijit Samanta, Brij Nandan, \\ Akhil Verma and Monika Banotra
}

Division of Agronomy, Sher-e-Kashmir University of Agricultural Sciences \& Technology of Jammu, Chatha, J\&K 180009, India

*Corresponding author

\begin{tabular}{l}
\hline Ke y w o r d s \\
Cropping systems, \\
Productivity, \\
Production \\
efficiency, Land- \\
use efficiency and \\
Economics \\
\hline Article Info \\
\hline $\begin{array}{l}\text { Accepted: } \\
\text { 28 August } 2020 \\
\text { Available Online: } \\
\text { 10 September } 2020\end{array}$ \\
\hline
\end{tabular}

Keywords

Cropping systems,

Productivity,

Production

efficiency, Land-

use efficiency and

Economics

Article Info

Accepted:

Available Online:

September 2020

\section{A B S T R A C T}

A field experiment was conducted during the rabi and kharif seasons of 2014-15 and 2015-16 at PRSS, Samba, SKUAST-Jammu, to evaluate the productivity, economics and efficiency of 4 rabi crops involving chickpea (Cicer arietinum L.), field pea (Pisum sativum L.), mustard (Brassica juneca L.) and gobhi sarson [Brassica juneca (L.), in system with 4 different kharif crops viz. Moongbean (Vigna radiata L.), Urdbean (Vigna munga L.), til (Vigna radiata L.) and soybean (Glycine max L.). System productivity of different cropping system in terms of chickpea-equivalent yield (CEY) was significantly higher under Field pea-moongbean with $(28.81 \mathrm{q} / \mathrm{ha})$ and $(28.88 \mathrm{q} / \mathrm{ha})$ during $2014-15$ and $2015-16$. Field peamoongbean and field pea-urdbean systems recorded the highest production efficiency (PE) based on CEY (kg CEY/ha/day). Land-use efficiency (LUE) was higher in chickpea- soybean and gobhi sarson-soybean systems than rest of the system whereas net return was registered highest in field pea-moongbean system during both the years respectively.

\section{Introduction}

India is one of the major oilseed and pulse producing countries in the world. Oilseeds and pulses are the two major groups of crops on which Government of India is giving special emphasis to enhance their production so as to avoid heavy import bill every year (Om, 2013). The state of Jammu and Kashmir is deficient not only in cereals but in pulse and oilseed grains also and the deficit is higher for pulses and oilseeds than cereals (Anonymous, 2013-14). National production of pulse is 22.95 million tonnes with the productivity of $779 \mathrm{~kg} / \mathrm{ha}$ from an area of 294.65 lakh hectare (Anonymous, 20172018). The area, production and productivity of pulses in the State of Jammu and Kashmir is 15.01 thousand hectares, 93.00 thousand quintals and $8.78 \mathrm{q} / \mathrm{ha}$, respectively 
(Anonymous, 2016). On the other hand, oilseeds have been regarded as the backbone of agricultural economy of India since long. India is the fifth largest economy in the word (Lakshman et al., 2017). Oilseed crops play the second important role in the Indian agricultural economy next to cereals in terms of area and production .The per capita availability of edible oils have increased from $4.0 \mathrm{~kg}$ per year in 1960-61 to $9.5-10.0 \mathrm{~kg}$ per year in India (Mandal et al., 2015). National production of oilseeds is 32.10 million tonnes with the productivity of $1225 \mathrm{~kg} / \mathrm{ha}$ from an area of 262.06 lakh hectare (Anonymous, 2017-18). It is further added that among all the crops which are commonly grown by the farmers on dry lands of Jammu, oilseed and pulse crops occupy a unique position as they have comparatively the better capabilities to sustain high moisture deficits as compared to maize and wheat. Besides this the pulses are valued for their importance in nutritional security and pulse-oilseed sequences are well known for their soil amelioration and sustainable crop production impacts (Ali et al., 2012).

\section{Materials and Methods}

A Field experiment was conducted during rabi 2014-15 to kharif 2016 at the Pulse Research Sub Station, Samba of Sher-eKashmir University of Agricultural Sciences and Technology of Jammu, J\&K. the soil was sandy loam $(71.70 \%$ sand and $16.80 \%$ silt and $11.50 \%$ clay) with $\mathrm{pH} 6.74$, electrical conductivity $0.15 \mathrm{dS} / \mathrm{m}$ in the top $15 \mathrm{~cm}$ of soil. The soil was low in available nitrogen (142.89 kg/ha) and sulphur (7.45 ppm/ha), medium in available phosphorus (10.72 $\mathrm{kg} / \mathrm{ha})$, potassium $(154.36 \mathrm{~kg} / \mathrm{ha})$ and organic carbon $(0.42 \%)$. The treatments comprised 16 cropping systems, viz. Moongbean $p b$ chickpea, Urdbean $p b$ Chickpea, Til $p b$ Chickpea, Soybean $p b$ Chickpea, Moongbean $p b$ Field Pea, Urdbean $p b$ Field Pea, Til $p b$
Field Pea, Soybean $p b$ Field Pea, Moongbean $p b$ Mustard, Moongbean $p b$ Gobhi sarson, Urdbean $p b$ Mustard, Urdbean $p b$ Gobhi sarson, Til $p b$ Gobhi sarson and Soybean $p b$ Gobhi sarson. The experiment was laid out in randomized block design and replicated four times. The RDF of chickpea, field pea, mustard, gobhi sarson, moongbean. Urdbean, til and soybean were 16:40:0:0, 16:40:0:0, 60:30:15:20, 50:30:15:20, 16:40:0:0, 16:40:0:0, 20:10:0:0 and 20:40:20:0 kg N: $\mathrm{P}_{2} \mathrm{O}_{5}: \mathrm{K}_{2} \mathrm{O}: \mathrm{S}$ /ha respectively. The fertilizers were applied as per recommended method and time of application for each crop. The total rainfall received during crop growing period of oilseed and pulse crops viz. chickpea, field pea, mustard and gobhi sarson was 519.68, 350.92, 425.72, 501.64 and 218, 105.23, 181.92 and $218 \mathrm{~mm}$ during rabi 2014-15 and 2015-16 respectively. The total rainfall received during kharif oilseed and pulse crops viz. moongbean, urdbean, til and soybean was 1134.99, 1134.99, 1364.53, 1441.97 and 851.8, 860.82, 878.84 and $878.84 \mathrm{~mm}$ during year 2015 and 2016 respectively. Relatively well distributed rainfall was received during $2^{\text {nd }}$ year of both rabi and kharif season. The average monthly air temperature was almost similar during both the years. Rabi oilseed/pulse crops was sown in the fourth week of October and harvested in the month of March (Field pea and mustard) and April (Gobhi sarson and chickpea). The kharif oilseed/pulse crops (moongbean, urdbean, til and soybean) were sown in the fourth week of June and harvested in the month of September (Moongbean, Urdbean and til) and October (Soybean). Economic yields of the component crops were converted to chickpea-equivalent yield (CEY), taking into account the prevailing minimum support price (MSP)/market prices of the crops. System productivity was calculated by adding the CEY of the component crops. Production efficiency (PE) was expressed as the ratio of 
system productivity in $\mathrm{kg} \mathrm{CEY/ha} \mathrm{to} \mathrm{total}$ duration of the system in days in a year during which they occupied the land. Total field duration of a cropping system expressed in percentage of 365 days was taken as the landuse efficiency (LUE) of the system. WUE was calculated by dividing the economic yield by consumptive use of water. Statistical analysis of the data was carried out using standard analysis of variance (Gomez and Gomez, 1984).

\section{Results and Discussion}

\section{System productivity}

System productivity in terms of chickpea equivalent yield(CEY) indicated that field pea-moongbean registered significantly highest system productivity and was statistically at par with field pea-urdbean and field pea- soybean system, where as lowest was registered in chickpea-til system during both the years (Table 1). This improvement in productivity may be attributed mainly to field pea and moongbean which fetched higher price in the market besides having good productivity than rest of the cropping systems. These findings are in close conformity with Kathirvelan et al., (2012); Ram et al., (2012); Singh et al., (2012); Usadadiya et al., (2014) and Prasad et al., (2016).

\section{Production efficiency}

More the grain produced in a shorter period more is production efficiency. Production efficiency of different rabi oilseed/pulsekharif oilseed/pulse systems was influenced significantly by yield of different crops in the systems. Field pea-moongbean system recorded significantly highest production efficiency followed by field pea-urdbean and field pea- soybean system (Table 1). This was due to the fact that field pea and moongbean had higher potential for efficient utilization of physical resources in short time as lesser number of days taken to maturity than oilseed and other pulse crops grown in the sequences. These results are in concurrence to the research studies of Sharma (2000); Shanmugam et al., (2012) and Singh et al., (2012).

\section{Land use efficiency}

In the present investigation, land utilization markedly increased due to inclusion of long duration crops (chickpea, gobhi sarson and soybean) in the system, indicated a better utilization of the land which was occupied for more number of days in a year under intensive multiple cropping system. Chickpea-soybean system expressed maximum land use efficiency followed by gobhi sarson-soybean system and least in field pea-moongbean system during both the years (Table 1). This might be ascribed to occupation of land by chickpea and soybean crops of this system for longer period. These results are in close agreement with Tripathi and Rathi (2002), Kathirvelan et al., (2012); Ram (2012) and Shanmugam et al., (2012).

\section{System economics}

Economic analysis of chickpea equivalent as influenced by cropping systems revealed that cost of cultivation and net returns were relatively higher during $2^{\text {nd }}$ year than first year (Table 2). Highest net return and benefit cost ratio were obtained in field peamoongbean system followed by field peaurdbean system. This might be due to higher production of field pea and moongbean crops in this system along with their higher market price of their produce. These results are in close agreement with the findings of Pandhi (1993), Patil et al., (1995), Shivakumar and Ahlawat (2008) and Kathirvelan et al., (2012). 
Table.1 System productivity, production efficiency and land use efficiency of different rabi oilseed /pulse- Kharif oilseed / pulse systems taken from rabi 2014-15 to kharif 2016

\begin{tabular}{|c|c|c|c|c|c|c|c|c|c|}
\hline \multirow[t]{3}{*}{ Treatments } & \multirow{2}{*}{\multicolumn{3}{|c|}{$\begin{array}{c}\text { System productivity } \\
\text { (q/ha) }\end{array}$}} & \multicolumn{3}{|c|}{ Production efficiency } & \multirow{2}{*}{\multicolumn{3}{|c|}{$\begin{array}{l}\text { Land use efficiency } \\
\text { (per cent) }\end{array}$}} \\
\hline & & & & & & & & & \\
\hline & $\mathbf{K Y} \mathbf{Y}_{1}$ & $\mathrm{KY}_{2}$ & $\begin{array}{l}\text { Over all } \\
\text { mean }\end{array}$ & $\mathrm{KY}_{1}$ & $\mathrm{KY}_{2}$ & $\begin{array}{c}\text { Over all } \\
\text { mean }\end{array}$ & $\mathrm{KY}_{1}$ & $\mathbf{K Y}_{2}$ & $\begin{array}{l}\text { Over all } \\
\text { mean }\end{array}$ \\
\hline $\mathrm{T}_{1}$ : Chickpea- moongbean system & 19.10 & 22.13 & 20.62 & 7.67 & 9.11 & 8.39 & 68.22 & 66.58 & 67.40 \\
\hline$T_{2}:$ Field pea-moongbean system & 27.93 & 29.68 & 28.81 & 12.99 & 14.20 & 13.60 & 58.90 & 57.26 & 58.08 \\
\hline $\mathrm{T}_{3}:$ Mustard-moongbean system & 21.30 & 24.19 & 22.74 & 9.55 & 11.10 & 10.32 & 61.10 & 59.73 & 60.41 \\
\hline$T_{4}:$ Gobhi sarson-moongbean system & 23.80 & 25.97 & 24.88 & 9.96 & 11.15 & 10.55 & 65.48 & 63.84 & 64.66 \\
\hline$T_{5}:$ Chickpea-urdbean system & 17.11 & 21.52 & 19.32 & 6.69 & 8.54 & 7.61 & 70.14 & 69.04 & 69.59 \\
\hline$T_{6}:$ Field pea-urdbean system & 27.18 & 28.93 & 28.05 & 12.24 & 13.27 & 12.76 & 60.82 & 59.73 & 60.27 \\
\hline $\mathbf{T}_{7}:$ Mustard-urdbean system & 20.98 & 23.92 & 22.45 & 9.12 & 10.54 & 9.83 & 63.01 & 62.19 & 62.60 \\
\hline $\mathbf{T}_{8}$ : Gobhi sarson-urdbean system & 23.74 & 25.70 & 24.72 & 9.65 & 10.62 & 10.13 & 67.40 & 66.30 & 66.85 \\
\hline $\mathrm{T}_{9}:$ Chickpea - til system & 13.79 & 17.76 & 15.78 & 5.23 & 6.83 & 6.03 & 72.33 & 71.23 & 71.78 \\
\hline$T_{10}:$ Field pea- til system & 22.96 & 25.01 & 23.98 & 9.98 & 11.07 & 10.52 & 63.01 & 61.92 & 62.47 \\
\hline$T_{11}:$ Mustard- til system & 17.33 & 20.19 & 18.76 & 7.28 & 8.59 & 7.94 & 65.21 & 64.38 & 64.79 \\
\hline$T_{12}:$ Gobhi sarson- til system & 20.13 & 21.80 & 20.97 & 7.93 & 8.72 & 8.32 & 69.59 & 68.49 & 69.04 \\
\hline$T_{13}:$ Chickpea-soybean system & 17.48 & 20.09 & 18.78 & 6.01 & 7.02 & 6.52 & 79.73 & 78.36 & 79.04 \\
\hline$T_{14}$ : Field pea-soybean system & 26.89 & 27.74 & 27.31 & 10.46 & 11.01 & 10.74 & 70.41 & 69.04 & 69.73 \\
\hline$T_{15}:$ Mustard-soybean system & 20.42 & 22.53 & 21.48 & 7.71 & 8.63 & 8.17 & 72.60 & 71.51 & 72.05 \\
\hline$T_{16}$ : Gobhi sarson-soybean system & 23.16 & 24.42 & 23.79 & 8.24 & 8.85 & 8.54 & 76.99 & 75.62 & 76.30 \\
\hline $\operatorname{SEm}( \pm)$ & 0.65 & 0.68 & 0.47 & 0.23 & 0.26 & 0.18 & - & - & - \\
\hline $\operatorname{LSD}(p=0.05)$ & 1.86 & 1.95 & 1.33 & 0.67 & 0.74 & 0.52 & - & - & - \\
\hline
\end{tabular}


Table. 2 Cost of cultivation, gross returns, net returns and benefit cost ratio of different rabi oilseed/pulse- Kharif oilseed / pulse systems taken from rabi 2014-15 to kharif 2016

\begin{tabular}{|c|c|c|c|c|c|c|c|c|c|c|c|c|}
\hline \multirow[t]{2}{*}{ Treatments } & \multicolumn{3}{|c|}{ Cost of cultivation (Rs./ha) } & \multicolumn{3}{|c|}{ Gross returns (Rs./ha) } & \multicolumn{3}{|c|}{ Net returns (Rs./ha) } & \multicolumn{2}{|c|}{ B:C Ratio } & \multirow[b]{2}{*}{$\begin{array}{l}\text { Over } \\
\text { all } \\
\text { mean }\end{array}$} \\
\hline & $\mathbf{K Y} \mathbf{Y}_{1}$ & $\mathbf{K Y}_{2}$ & $\begin{array}{l}\text { Over all } \\
\text { mean }\end{array}$ & $\mathbf{K Y}_{1}$ & $\mathbf{K Y}_{2}$ & $\begin{array}{l}\text { Over all } \\
\text { mean }\end{array}$ & $\mathbf{K Y}_{1}$ & $\mathbf{K Y}_{2}$ & $\begin{array}{l}\text { Over all } \\
\text { mean }\end{array}$ & $\begin{array}{l}\text { KY } \\
1\end{array}$ & $\mathbf{K Y}_{2}$ & \\
\hline $\mathrm{T}_{1}$ : Chickpea moongbean system & 37447.71 & 37774.93 & 37611.32 & 60632.50 & 75809.00 & 68220.75 & 23184.79 & 38034.07 & 30609.43 & 0.62 & 1.01 & 0.81 \\
\hline $\mathrm{T}_{2}$ : Field pea-moongbean system & 36299.67 & 36838.14 & 36568.91 & 88666.00 & 101669.00 & 95167.50 & 52366.33 & 64830.86 & 58598.60 & 1.44 & 1.76 & 1.60 \\
\hline $\mathrm{T}_{3}:$ Mustard-moongbean system & 34365.76 & 34677.18 & 34521.47 & 67625.00 & 82846.00 & 75235.50 & 33259.24 & 48168.82 & 40714.03 & 0.97 & 1.39 & 1.18 \\
\hline $\mathbf{T}_{4}$ : Gobhi sarson-moongbean system & 34280.76 & 34592.18 & 34436.47 & 75559.00 & 88944.50 & 82251.75 & 41278.24 & 54352.32 & 47815.28 & 1.20 & 1.57 & 1.39 \\
\hline $\mathrm{T}_{5}:$ Chickpea-urdbean system & 37347.71 & 37724.93 & 37536.32 & 54340.00 & 73702.75 & 64021.38 & 16992.29 & 35977.82 & 26485.06 & 0.45 & 0.95 & 0.71 \\
\hline $\mathbf{T}_{6}$ : Field pea-urdbean system & 36199.67 & 36788.14 & 36493.91 & 86286.00 & 99074.50 & 92680.25 & 50086.33 & 62286.36 & 56186.35 & 1.38 & 1.69 & 1.54 \\
\hline $\mathbf{T}_{7}:$ Mustard-urdbean system & 34265.76 & 34627.18 & 34446.47 & 66623.50 & 81912.50 & 74268.00 & 32357.74 & 47285.32 & 39821.53 & 0.94 & 1.37 & 1.16 \\
\hline $\mathbf{T}_{8}$ : Gobhi sarson-urdbean system & 34180.76 & 34542.18 & 34361.47 & 75364.50 & 88009.75 & 81687.13 & 41183.74 & 53467.57 & 47325.66 & 1.20 & 1.55 & 1.38 \\
\hline $\mathrm{T}_{9}:$ Chickpea - til system & 35103.51 & 35191.03 & 35147.27 & 43796.50 & 60832.00 & 52314.25 & 8692.99 & 25640.97 & 17166.98 & 0.25 & 0.73 & 0.49 \\
\hline$T_{10}:$ Field pea- til system & 33955.47 & 34254.24 & 34104.86 & 72888.00 & 85657.00 & 79272.50 & 38932.53 & 51402.76 & 45167.65 & 1.15 & 1.50 & 1.32 \\
\hline$T_{11}:$ Mustard- til system & 32021.56 & 32093.28 & 32057.42 & 55021.00 & 69147.50 & 62084.25 & 22999.44 & 37054.22 & 30026.83 & 0.72 & 1.15 & 0.94 \\
\hline$T_{12}:$ Gobhi sarson- til system & 31936.56 & 32008.28 & 31972.42 & 63921.00 & 74665.00 & 69293.00 & 31984.44 & 42656.72 & 37320.58 & 1.00 & 1.33 & 1.17 \\
\hline $\mathbf{T}_{13}$ : Chickpea-soybean system & 41786.71 & 41869.53 & 41828.12 & 55490.90 & 68804.00 & 62147.45 & 13704.19 & 26934.47 & 20319.33 & 0.33 & 0.64 & 0.49 \\
\hline$T_{14}$ : Field pea-soybean system & 40638.67 & 40932.74 & 40785.71 & 85372.80 & 95010.00 & 90191.40 & 44734.13 & 54077.26 & 49405.70 & 1.10 & 1.32 & 1.21 \\
\hline$T_{15}:$ Mustard-soybean system & 38704.76 & 38771.78 & 38738.27 & 64841.00 & 77159.50 & 71000.25 & 26136.24 & 38387.72 & 32261.98 & 0.68 & 0.99 & 0.83 \\
\hline$T_{16}:$ Gobhi sarson-soybean system & 38619.76 & 38686.78 & 38653.27 & 73530.60 & 83630.00 & 78580.30 & 34910.84 & 44943.22 & 39927.03 & 0.90 & 1.16 & 1.03 \\
\hline
\end{tabular}


Another possible reason for highest value might be due to short duration of crops reducing their infestation to insect pest and early harvest reducing the cost of maintenance in the field. These findings are in close agreement with Patton and Gohain (2011).

\section{References}

Ali, M., Kumar, N. and Ghosh, P. K. 2012. Milestones on Agronomic research in pulses in India. Indian Journal of Agronomy, $57 \quad\left(3^{\text {rd }}\right.$ International Agronomy Congress) Nov.26-30: 52-57

Anonymous, 2015-16. Digest of Statistics, Directorate of economics and statistics, Govt. of Jammu and Kashmir,pp-14748

Anonymous, 2017-18. Annual Report, Department of Agriculture, Corporation and Farmers Welfare, Ministry of Agriculture and Farmers Welfare, Govt. of India, Krishi Bhawan, New Delhi. pp- 3

Anonymous. (2013-14b). Economic Survey, Directorate of Economics and Statistics. Govt. of Jammu \& Kashmir, pp-194

Kathirvelan, P., Balasubramanian and Siddeswaran, K. 2012. Crop diversification: Enhancing the system productivity and profitability through on farm research. $3^{\text {rd }}$ Extended summaries (2): $\quad 3^{\text {rd }}$ International Agronomy Congress, Nov.26-30:409 - 410

Lakshman, K., Vyas A. K., Shivakumar B.G., Rana D.S., Layek J. and Munda S. 2017. Direct and residual effect of sulphur fertilization on growth, yield and quality of mustard in a soybean mustard cropping system. International Journal of Current Microbiology and Applied Sciences, 6(5): 1500-1512.

Mandal, Debkanta and Chattopadhyay G.N.2015.Balanced nutrient management of mustard (Brassica juncea 1.) in rice-mustard- sesame cropping system in red and lateritic soil. International Journal of Plant, Animal and Environmental Sciences, 5(1)

Om, H. 2013. Moisture and nutrient management in green gram (Vigna radiata) - mustard (Brassica juncea) cropping system under limited moisture conditions. Ph.D thesis. Division of Agronomy, Indian Agricultural Research Institute New Delhi-110 012

Prasad, D., Rana, D. S., Babu S., Choudhary, A. K. and Rajpoot, S. 2016. Influence of tillage practices and crop diversification on productivity and soil health in maize (Zea mays)/soybean (Glycine max) based cropping systems Indian Journal of Agricultural Sciences, 86 (1): 96-102

Ram, A. J., Dungrani, R. A., Arvadia, M. K. and Sahrawat, K. L. 2012. Diversification of rice (Oryza sativa L.)-based cropping systems for higher productivity, resource-use efficiency and economic returns in south Gujarat, India. Archives of Agronomy and Soil Science, 58(6): 561-572

Richards, R. A., Rebetzke, G.J., Condon, A.G. and Herwaarden, A. F. V.2002. Breeding opportunities for increasing efficiency of water use and crop yield in temperate cereals. Crop Science, 42: 111-121

Sadras, V. O. 2003. Influence of size of rainfall events on water driven processes I. Water budget of wheat crops in south-eastern Australia. Australian Journal of Agriculture Research, 54: 341-351

Tripathi, S.C. and Singh, R.P. 2008. Effect of crop diversification on productivity and profitability of rice (Oryza sativa) wheat (Triticum aestivum) cropping system. Indian Journal of Agronomy 53(1): 27-31.

Usadadiya V. P., Patel R. H. and Hirapara B. V.2014. Effect of preceding crops and 
nutrient management on growth productivity and quality of wheat in irrigated conditions. International Journal of Agriculture Innovations and Research, 2(4) pp. 463-465.
Wanga, X., Gana, Y., Hamela, C., Lemkeb, R., Cal McDonalda. 2012. Water use profiles across the rooting zones of various pulse crops. Field Crops Research 134: 130-137.

\section{How to cite this article:}

Rakesh Kumar, B.C. Sharma, Abhijit Samanta, Brij Nandan, Akhil Verma and Monika Banotra. 2020. Production Potential of Oilseed -Pulses Cropping Systems under rainfed Ecology of Shivalik Foothills of Jammu. Int.J.Curr.Microbiol.App.Sci. 9(09): 3663-3669. doi: https://doi.org/10.20546/ijcmas.2020.909.452 